DOI: https://doi.org/10.47405/aswj.v5i1.129

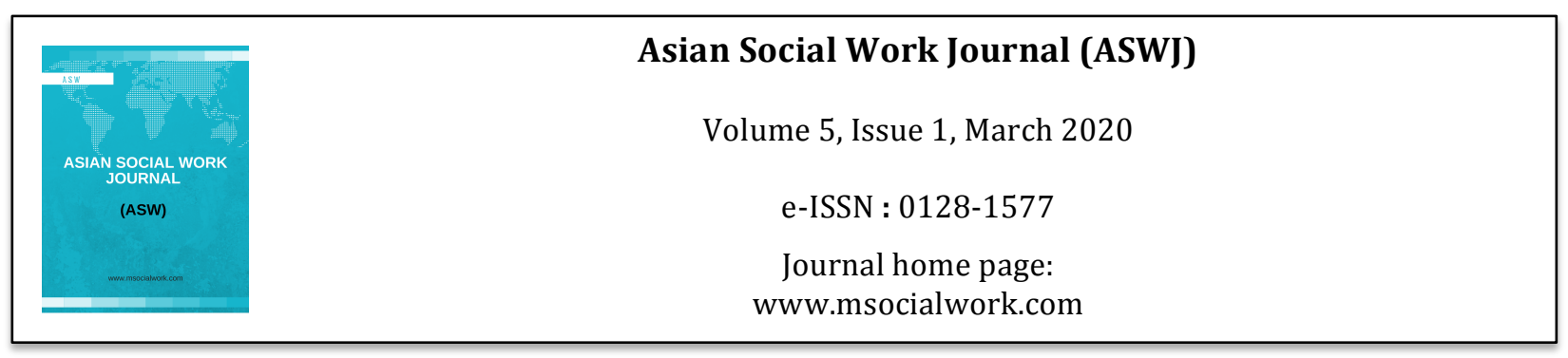

\title{
The Implementation of Psychosocial Therapy on the Victims of Landslide Disaster in Banjarnegara Central Java Province, Indonesia
}

\author{
Meiti Subardhini ${ }^{1}$ \\ 1Sekolah Tinggi Kesejahteraan Bandung, Indonesia
}

Correspondence: Meiti Subardhini (meiti.subardhini@gmail.com)

\begin{abstract}
Anxiety, Stress and Trauma are psychosocial conditions and labels for people who have suffered from any disasters and they areperceivably traumatized and unable to rise up from their adversity. Therefore, psychosocial recovery through various ways, especially therapy, becomes an alternative healing treatment for them. This study was aimed to examine the extent to which the implementation of psycho-medical therapy especially cognitive and behavioral therapy for the victims of landslides disaster in Banjarnegara. It was required to analyze how the effectiveness of psychosocial therapy was for stress and trauma undergone by the victims of landslide disaster in Banjarnegara. In practice, nourishment and visualization techniques of cognitive approach became an option to carry out at an early stage through several meetings. Furthermore, technique of systematic desentization and task orientation into advanced techniques performed on the victims of landslide disaster also went through several meetings. The procedure of the technique was carried out by two stages that divide the application of cognitive and behavioral approaches. Assessment and therapy function turn out to be the factor considered in this research, that the occuring change can be observed from the research subject. This research used qualitative descriptive methodology based on action research study, which basically requires describing the application of various techniques in psychosocial therapy conducted on three persons (3) of disaster victims as the research subject. The results of this research will perceivably benefit the research subject, as well as for the enrichment and experience of clinical social workers in various settings in overcoming psychosocial problems.
\end{abstract}

Key words: psychosocial therapy, disaster victims, landslides disaster, healing

\section{Introduction}

Natural disaster is an unpredictale natural event that everyone finds it very dreadful. Therefore, it is certain that every disaster victim will suffer an alarming psychosocial condition. Psychosocial condition of disaster victims varies to a great extent depending on the strategic coping they have. They from mild to acute or chronic symptoms. Among the feelings are: sadness, anxiety, stress, grief, trauma, and depression. Therefore, a proper understanding of their psychosocial condition is important to recognize by the social workers who will assist the recovery of disaster victims. By this research appropriate techniques or therapy can be identified to deal with psychosocial conditions experienced by disaster victims.

The conceptual review has identified some psychosocial conditions suffered by disaster victims. Some experts stated it concerning sadness, stress, trauma and depression. Sadness is a natural response to the state of loss, harm, and separateness, as well as emotional distress that the child perceives when the 
DOI: https://doi.org/10.47405/aswj.v5i1.129

situation or someone we love/care about is being taken away or lost. Disaster victims undergo the situation as they suffer from the death of their loved ones, loss of property or separation with family members and social environment. This leads to the most terrible sadness (Sutardjo, 2004).

Stress is an arousing state that occurs in a person when his/her equilibrium is disrupted caused by any change of situation that comes from a person and/or the environment. Another expert postulated that stress is: "an influence of matters regarded as the challenge in life, sensible choices someone shall take in which his equilibrium is disrupted, and he/she is required to have adaptive response. Stress is the result of an external or internal situation that creates pressure. People who are undergoing any threats (critical incidents) in their lives or other traumatic experiences have a risk of psychological distress (Dadang Hawari, 2011).

Stress can be characterized by: Any changes that occur slowly or gradually in people who undergo stress, as it leads to problems that can generally be resolved over time; people affected by stress can still make decisions, as it does not lead to trauma.

From various sources of stress undergone by disaster victims, it can generally be classified into mild stress that leads to severe and acute to chronic stress. Mild leading to severe stress can be represented as the condition undergone by disaster victims regarding the daily experiences related to their routines in post-disaster conditions, including: queuing for basic needs, dealing with volunteers/social/health workers etc., to the experience of more complex nature, such as the loss of loved ones, the watching the wreckage of burnt house, and so forth.

While acute leading to chronic stress can be considered as an example indicated when disaster victims must go through a new change related to their role to survive post-disaster event is perceivably threatening and being a source of acute stress, for instance: having no family or close relative, being orphaned, the head of family/financial provider for the family, etc.

Stress can represent various reactions in each person; generally, this reaction involves aspects such as: physical; which is a reaction that can be observed by others or only perceived by the victim, therefore this physical reaction occurs mechanically but includes uncontrolled reaction by the suffering people. Mind; this aspect is perceived by the victim in the form of a situation in which the disaster event crosses one's mind and then it is developed according to his/her own mind. For example, a father who thinks that he is unable to educate and raise his childrendue to the loss of his wife in a disaster event. Emotions; deal with the stress of different types of emotions perceived by a person and influenced by the source of one's stress. It is also influenced by the body's perceived biological processes, such as headaches and rapid heartbeats whilerecollectingthe deceased ones out of a catastrophe that creates deep, heartbreaking emotion. Behavior; this aspect is the most obvious stress reaction that can be observed by others. For example: a crying child, a daydreaming mother, a quiet father and other behaviors that the victim express as a result of the loss and disaster events that befall upon them. Consequently, they experience social functioning impediment characterized by obstacles in performing their social roles. Another expert, Schuler (2002) defined that stress is a dynamic state when one is exposed to opportunities, demands, or sources of power related to what the individual wants and which results are deemed to be uncertain and insignificant. Stress is a psychological problem that exceeds the maximum ability it leads to the ill-controlled behaviours. Stress is not continually viewed in negative context. This is because stress has a positive value when it becomes an opportunity in offering potential outcomes, for example, as a positive challenge to improve the work quality (Lazarus, R.s \&Folkman, S. 1984).

Another psychosocial condition that can also befall upon disaster victims is trauma. Trauma is a sense of depression, helplessness, tremendous fear of painful, dreadful or depressing experiences. Trauma can be pain or shock. Psychologically trauma refers to shocking and painful experiences that transcend the stressful situation under normal conditions.

Trauma can be demonstrated by at least three different phases, namely: the phase of impact period, which is a period that occurs during the event, the recoil period, which is a period that occurs within a 
DOI: https://doi.org/10.47405/aswj.v5i1.129

few days after the victim's release, the post-trauma period, which starts from the process of law in the court, it could lasts longer and presumably lifelong.

An intervention of social workers in dealing with the disaster victims among others is psychosocial therapy. It is a method of healing in which the knowledge about: bio-psycho-social human and social behavior, the skills in relating to individuals, families, groups and communities, the competence in mobilizing available resources are combined in the medium of relationships of individuals, families and groups in order to help people changing their personalities, behaviors, or situations that can contribute to the achievement of satisfaction, fulfillment of human needs within the framework of personal values, personal goals, and available resources in society (Turner 1978). Furthermore, Payne (1997), considered that psychosocial approaches in social work focuses particularly on "How relationships are shaped and managed by people in certain social situations". The issues raised through psychosocial therapy include: stigma issues, group behavior, environmental influences, territoriality, the need for personal space, and personal and social change (Zastrow 2002). The objectives of psychosocial therapy are expected to: contribute to the achievement of satisfaction, fulfill human functioning within the framework of personal values, and access the available resources in society (Turner, 1978).

Psychosocial issues addressed through psychosocial therapy include: relating to normality and abnormality in social functioning, as one is considered normal in functioning if: he/she has sufficient or adequate bio-psycho-social qualities, having sufficient or adequate sense of self, liberated from acute internal infliction, anxiety, fear, compulsive, anger and psychosomatic conditions, having a sense of usefulness, identifying his/her wellbeing, recognizing that he/she is an important part (Hollis F 1970).

By psychosocial therapy interventions conducted on disaster victims, it is expected that they will go through some changes, as pointed out by Turner and Zastrow that the changes occuring from psychosocial therapy interventions include: cognitive, emotive, behavioral, and environmental changes as well as alleviating infliction (Turner 1978, Zastrow 2002).

Psychosocial therapy in its implementation can be applied by: individual, group, family, or community therapy. Many techniques in psychosocial therapy are appropriate/effective to use in dealing with psychosocial problems undergone by disaster victims. In this study, it used engineering techniques that include cognitive and behavioral approach.

\section{Research Methodology}

The research method used qualitative, which is a systematic analysis of social activities conducted through observation to the research subjects in detail in the actual setting, which is intended to gain understanding and interpretation of how people create and maintain the social world (Mulyana, 2002; Sugiyono, 2007). The type of analysis conducted in this study is in the form of social action (action research).

\section{Research Subject}

The research subjects were carried out by incidental sampling technique, the researcher came to the residence of 3 subjects based on information from the community about the condition of the subject with the characteristics of stress and trauma after losing their Klg members due to the disaster. This research was carried out within 3 months by giving therapy once a week.

\section{Objectives and Benefits of Research}

Assessing the extent of social worker interventions through Cognitive and Behavioral Therapy can address the psychosocial problems of disaster victims especially stress and trauma, by procedures of some predetermined techniques, and analyze the process of social clinical work interventions to figure 
DOI: https://doi.org/10.47405/aswj.v5i1.129

out problem-solving for victims of natural disasters as well as increasing skills of social workers in carrying out psychosocial therapies.

\section{Research Process}

The research process was carried out as follows: The first 2 weeks of conducting the assessment, after which therapy was carried out for 10 weeks (once a week carried out therapy) so that overall the study was for 3 months

\section{Research Results and Discussion}

\section{The first session}

The first session of this research was intended to identify the problems and assessment of 3 subjects, the result is as follows:

\section{Characteristics of research subjects and assessment results}

1. Stnm, is a 41-year-old woman who lost 9 family members including her child and mother, she works daily as housemaid in other city, furthermore she stated:

Stnm (41 years old), a woman who has been working as a housemaid in Jakarta, while she was not in the scene during the catastrophic event, she lost her youngest child, her mother, her sister and nine other family members. In front of othersshe attempted to be steadfast, even the neighbors admire her because she was able to help other victims directly at the scene as a volunteer. But behind it,she felt the deep sadness, tearfully she expressed her feelings that she felt very sinful leaving her child and mother behind.

She often thinks of her family who died because of the landslide, especially her child and mother, even a few days ago she dreamt of her child's body being carried by her husband, but afterwards Stnmfelt more comforts, even assumed that her child was resting in peace "up there".The guiltyfeeling for having leaving her child behind still hauntsher though...... But she often feels slightly aboveboard, surrendered all for this is destiny from the God Almighty...... sometimes the feelinggoes on and off.

2. Stp, a 43-year-old man lost his beloved grandchild, Stp earns a living by running a food stall located next to his house. His small shop and house were completely destroyed to the ground due to the natural disaster they have suffered from. Specifically Stp stated the following:

Stp (43 years old), a father/grandfather who during the disaster was buying a smashed fried chicken as his grandchild requested for dinner, when he saw his house and its belongings as well as his grandchild was completely destroyed to the ground. After the incident he always remembered and heard his grandchild's request for the smashed fried chicken that he could barely sleep and eat to date (10 days following the incident), he could not even see the child's toys as he remembered his grandson, that the sadness and guilty feeling always haunts him.

3. Snt, 50-year-old man, lost his wife and child, he earns his daily living as manual laborer, so his statements: 
Snt (50 th), a husband who lost his wife and son, as well as his possessions. A deep sadness has afflicted him for three days after the incident that he could hardly talk and move his neck (neck pain). His physical pain was already treated in the clinic available around the shelter. His physical condition gradually improves, but following 10 days after the disaster, he still could barely sleep and eat, that he always feels guilty for having no more chances to make his family happy.

When conducting short assessments for the three (3) subjects, researchers explored it by using social conversation and ventilation techniques that they could express their emotions albeit slowly but they seemed to feel enlightened. It is obvious on how they recounted the story, the tears they held up until finally they could cry and revealed some other expressions. There was not much trouble in the early stages as they were very opened, except Sntthat was somewhat reserved for it maybe because of his poor physical condition. The research subject seemed very keen and enthusiastic to express their emotions especially Stnm, while crying and occasionally squeezing her finger,but she kept telling her stories. Once she was settled down, I asked her about who was the closest one among the families who died from the disaster, she replied: "my son and simbok,"only if they can hear what she would say to her son.., after the client paused for a moment, then she managed to whisper the sentence: "......Son, forgive me, I love you, I want to meet you, but I am sincerely surrendered, may God accept you..... "While crying the client repeatedly uttered the sentence, then she expressed almost the same word for his mother. Afterwards, Stnm looked more peaceful, followed by a light relaxation.

This was the process of extraction of problems through social conversation and ventilation techniques which were further conducted for the three research subjects, of which purpose was for assessment as well as catharsis that they felt quite relaxed and proceed with other techniques. In addition to the above techniques were also empty chair techniques for Stnm and nourishment techniques for Stp, both techniques were the same purpose for catharsis and functions as an assessment.

Implementation of the first session (assessment) obtained results that: The three research subjects were generally under stress with symptoms: sleeping problems, eating problems, deep sadness, and unwillingness to see or approach the site of their former disaster-stricken homes. Besides that specifically Stnmdid not want to see any objects that remind of her deceased mother who died from the disaster, such as mattress, stove, etc. As for Stp, hedid not want to see the kid's toy such as bicycle, as it reminded him of the moment when his grandson was playing bike.

According to the researcher's observation and recognition of the research subjects, the above techniques effectively benefit them, it is obvious from their facial expressions that look happier after performing this technique, other than that, their feelings become more relievedas all problems have been issued. Researchers also had no difficulties in performing this technique and all research subjects can carry out this technique optimally.

\section{The second session}

Implementation of the second session was counseling techniques for Stnm and Snt, while the imaginal flooding technique was intended for Stp. The counseling process for both research subjects can run smoothly, through three stages of counseling, namely: trust building, exploring the issues in depth and deciding on alternative actions. The implementation of this counseling was conducted in two separate meetings for each research subjects. The results of this counseling process were: for Stnm, there were several alternative actions that will be gradually approach to the dreaded subject (objects as reminiscent of her deceased mother) and the disaster scene. As for Snt, he wanted to divert this issue on the work that has been delayed due to the disaster.

While the imaginal flooding technique was performed on Stp, with such process: By this imaginal flooding technique the research subjects were asked to recollect the whole series of events and classify them into 5 big scenes that will be excluded through this technique. In initial stage, Stp divided into 5 events/scenes during the occuring disaster that includes: the stage prior to disaster such as playing with 
DOI: https://doi.org/10.47405/aswj.v5i1.129

his grandchild, then closed his small shop as he intended to buy food at the request of his grandchild, then he left his grandson who was playing and entrusted him to his neighbor, he was buying his grandson's request in the square of the sub-district when he heard people running around shouting for landslide, he immediately ran back to the house and got to his house location and the entire area of his village had already been destroyed to the ground.

All scenes can be articulated by various heartbreaking stories and expressions, even in some scenes, Stp started crying and calling his grandson's name. For about two hours, this technique can be completed properly and smoothly. The therapy was concluded with mild relaxation for cooling down process and the client looked more relaxed with more radiant expression and according to his statement, he felt more enlightened or relieved.

\section{Third session}

This session was conducted through 3 meetings for each research subject, the researcher used techniques from behavioral approach that was systematic desensitization and Task centered separately for each research subject. For the first technique, each research subject was invited to identify and had mapping activities that made a fearful response to be approached, each event was made into 6 or more hierarchies after which each hierarchy was approached by assigning tasks to each hierarchy. For implementation of this technique, each subject represented different results. Stnm completed 6 hierarchies set within 8 days. Stp completed the 5 hierarchies set within 6 days while Stn completed the 5 hierarchies set in 4 days.

The results obtained and as the ultimate goal set in the series of psychosocial therapy, namely: Stnm was able to take a look at her most deadful objects such as mattresses and stoves (as reminiscent of her deceased mother) even chose to sell meatball and fried snacks and opted for her choice of location near to the disaster scene she did not even want to see previously.

Likewise, Stp chose to sell motorcycle parts and he also opted for the location adjacent to the disaster site, even he was able to display photos portraying his late grandchild along with his favorite bike in his room, whereas he was unable to recollect and take a look at his grandchild's picture, bicycles and approaching disaster site as frightening and sorrowful scene.

As for Stn, on the last day of therapy process, he had gone out of town to resume his delayed work as wood workers. This indicates that Stnwas able to leave the house even going to work of which he was previously dreadfuland even considered that it was useless to earn his living as there was nothing to gain more while his feeling of despair increased.

According to the researcher's observation, this third session can be accomplised well in prolonged time and it was varied between one to another research subject, as it highly depended on different coping and resilience process by each research subject. The success of various techniques in psychosocial therapy was well-recognized by the research subjectsas well as their families. In addition, it was obvious from their bright, radiant facial expressions and they would already socialize with other people in the shelter and new neighbors.

\section{Conclusion}

This study has been considered beneficial for disaster victims especially those including research subjects, including: releasing their emotions/problems by catharsis techniques, feelings more relieved as they can communicate the problem, relieving their mind or pressure on disaster events, alleviating anxiety over the event, managing to recount the disaster events to others, mitigating their sadness as they recollect their relatives and other family members who died from the disaster, able to take a look at the location of their former house,which was destroyed by the disaster, even now they decided to reside adjacent to the location and able to get back to the delayed activity (selling) in supportingtheir daily needs. These conditions, other than directly expressed by the recognition of research subjects, it 
DOI: https://doi.org/10.47405/aswj.v5i1.129

was also obvious from their facial expressions and the completion of tasks they must perform in accordance with their roles and functions in the family and community.

Other findings were the implementation of different psychosocial therapy techniques between one and other research subjects, depending on characteristics of the research subjects and the environment in which the treatment process was performed.

For the researcher as social worker, he/she can perform the role of therapist by techniques from cognitive approach and behavioral approach individually so as to have good practical experience especially in intervention to natural disaster victims.

Besides the success of psychosocial therapy conducted on the research subjects, there were many influencing factors, in addition to therapeutic process and appropriate choice of techniques, it was also highly dependent on coping strategies and resilience by each research subjectsas well as the timing that contribute to the healing from their psychosocial problems, as experts have suggested.

Based on this research, it can also be recommended to various parties who are competent in handling the victims of natural disasters generallyin order to provide advanced intervention for internal and external environment where they are located, especially for any symptoms which disaster victims may suffer in time, that basically these symptoms can be recurred such as grieving for the lost ones by stages of denial, range and anger, bargaining, depression, and acceptance in the cycleoccuring in the afflicted people.

Besides that for handling post-disaster stress and trauma cases it is recommended that further research using PTSD (Post Traumatic Stress Disorder) assessment also uses Cognitive Behavior Therapy (CBT) techniques for more comprehensive treatment.

\section{References}

Barker. (1995). The Social Work Dictionary. New York : Free Pres

DadangHawari (2011). StresCemasdanDepresi. Jakarta : Universitas Indonesia

Ehrenreich, J.H. (2001). Coping With Disaster: A Guidebook to Psychosocial Intervention. New York: Center For Psychology and Society state University of New York

Evans, G. W. (2000). Stress and Open-Office Noise. .Journal of Applied Psychology, 85(5):779-783.

Ferroni. (1990). Assortion. Perth: School of Social Work-Curtin University of Technology

Field. (2003). Self Esteem for Woman. Bandung: Kaifa

Frew, D. R. (1987). Percieved Organizational Characteristics and Personality Measures as Predictors of Stress/Strain in the Workplace. Journal of Management Winter, 13(4), 633-646.

Friedlander, W.A. (1977). Concepts and Methods of Social Work. New Delhi: Prentice Hall of India

Follette, V. M., Polusny, M. A., Bechtle, A., \&Naugle, A. (1996). Cumulative Trauma: Impact Of Child Sexual Abuse, Sexual Assault, And Spouse Abuse. Journal of Traumatic Stress, 9, 25-35.

Gochros, Harvey.L. (1979). Behavior Change and Modification. Englewood Cliffs.H.J: Prentice.

Hurlock, E. (1980). PsikologiPerkembangan. Jakarta: Erlangga

Hollis.F. (1964). Casework: A psychosocial Therapy (1 ${ }^{\text {st }}$ d). New York: random house

Hollis.F. (1970). The psychosocial approach to the practice of practice. In. R. Roberts \& R Nee(eds). Chicago University of Chicago press

Hollon, S.D.\& Beck, A.T.(1994). Cognitive and Cognitive Behavior Therapies. In Handbook of Psychothetapy of Behavior Change. New York: Wiley\& sons.

Howard, April.,Riger, Stephanie., Campbell, Rebecca., \& Wasco, Sharon. (1995). Counseling Services for Battered Women: A comparison of Outcomes for Physical and Sexual Assault Survivors. Chicago: University of Illinois Press.

J. Moleong. (2004). Penelitian Kualitatif. Bandung: PT. Rosdakarya

James, Drever. (1987). Kamus Psikologi. Jakarta: Bina Aksara Jurusan Rehabilitasi Sosial,

STKS Bandung (2006): Manual Terapi Psikososial 1. Tidak diterbitkan

Katz, Alfred. (1981). Self Help and Rehabilitation.Illinois: The Dorsey Press Hall. 
DOI: https://doi.org/10.47405/aswj.v5i1.129

Konopka, Gisela. (1954). Group Work the Institution: A Modern Challenge. New York: Association Press

Lazarus, R.s. \& Folkman, S. (1984). Stress, Appraisal and Coping. New York: Springler

Meiti Subardhini, Dorang Luhpuri, STKS Bandung (2011): Hand Out Mata Kuliah Terapi Psikososial dalam Pekerjaan Sosial. Tidak diterbitkan

Meiti Subardhini, Dorang Luhpuri, Ami Maryami, Irniyati Samosir, STKS Bandung (2013): Manual Terapi Psikososial 2 (Panduan Praktek Bagi Mahasiswa Pekerja Sosial)

Mulyana, Deddy. (2003). Metodologi Penelitian Kualitatif: Paradigma Baru Ilmu Komunikasi dan Ilmu Sosial lainnya. Bandung: PT Remaja Rosida Karya.

Pusat Krisis Fakultas Psikologi UI (2007): Pemulihan Trauma; (PanduanPraktis Pemulihan Trauma AkibatBencanaAlam). Tidak diterbitkan

Sutardjo Wiramihardja, (2004). Pengantar Psikologi Klinis; RefikaAditama Bandung

Turner, J. Francis. (1978). Psychosocial Therapy. New York: Macmillan Publishing Co.

Zastrow, H. Charles. (1999). The Practice Of Social Work (7 Ed). USA: Books/ Cole Publishing Company. 